УДК 796.011.1

\author{
Олександр Міщенко \\ ORCID ID 0000-0002-1157-198X, \\ Ніна Кулик \\ ORCID ID 0000-0001-7319-3753, \\ Лариса Прийменко \\ ORCID ID 0000-0002-7485-2295, \\ Олександр Міщенко \\ ORCID ID 0000-0003-4200-6294 \\ Сумський державний педагогічний \\ університет імені А. С. Макаренка \\ DOI 10.24139/2312-5993/2019.05/140-151
}

\title{
СТАВЛЕННЯ СТУДЕНТІВ-ПЕДАГОГІВ ДО ПРОЦЕСУ ФІЗИЧНОГО ВИХОВАННЯ В ЗАКЛАДАХ ВИЩОї ОСВІТИ
}

У статті представлено результати дослідження відношення студентів до процесу фізичного виховання у стінах педагогічного університету на сучасному етапі розвитку нашої держави. Аналіз анонімного анкетування вказує, що для покращення процесу фізичного виховання у вищому педагогічному навчальному закладі необхідно застосовувати низку факторів, представлених до розгляду авторами опитування, серед яких респонденти виділили, на їхню думку, найбільш значущі, а саме: підвищення фізичного навантаження, використання різноманітного спортивного інвентарю та обладнання, створення належних умов для різноманітної рухової активності, постійного оновлення матеріально-технічної бази.

Ключові слова: здоров'я, студент, фрізичне виховання, матеріально-технічне забезпечення, фрізичне навантаження.

Постановка проблеми. Здоров'я населення, особливо підростаючого покоління, $€$ постійною проблемою в Україні, що підкреслює і Указ Президента України №42 від 2016 р. «Про Національну стратегію 3 оздоровчої рухової активності в Україні на період до 2025 року «Рухова активність - здоровий спосіб житт - здорова нація» (Указ Президента України...). Зокрема вказано, що «...результати всеукраїнського опитування свідчать, що на початку XXI століття достатній рівень оздоровчої рухової активності (не менше 4-5 занять на тиждень тривалістю одного заняття не менше 30 хвилин) мали лише 3 \% населення віком від 16 до 74 років, середній рівень (2-3 заняття на тиждень) - 6 \%, низький рівень (1-2 заняття на тиждень) - 33 \% населення. Для більшої частини дорослого населення характерною $є$ гіпокінезія. Серед дітей зростає популярність малорухомого способу проведення дозвілля». 
Для виконання завдання стратегії держави щодо «формування ціннісного ставлення юнацтва та молоді до власного здоров'я, покращення фізичного розвитку та фізичної підготовленості з урахуванням вимог майбутньої професійної діяльності» (Указ Президента України...) і виникає потреба у виявленні ставлення студентів закладів вищої освіти до занять фізичним вихованням під час навчального процесу.

Аналіз актуальних досліджень. У сучасних умовах в Україні склалася критична ситуація зі станом здоров'я підростаючого покоління, де понад 90 \% дітей різної вікової групи мають відхилення в стані здоров'я, незадовільна фізична підготовка - у 50 \%. 61 \% молоді віком 16-19 років мають низький та нижче середнього рівень фізичного здоров' я, а 67,2 \% - у віці 20-29 років. За останні п'ять років на 41 \% збільшилася кількість молоді, яка відноситься за станом здоров'я до спеціальної медичної групи (Кузнєцова та ін., 2015; Сотник, 2013; Masliak et al., 2018).

Статистичні дані Н. А. Кулик та С. В. Гудим (2018) указують, що кожного року до закладів вищої освіти вступають абітурієнти із слабкою фізичною підготовкою та станом здоров'я. Дослідження науковців Є. П. Баліцької (Баліцька, 2013), М. М. Булатової, Ю. О. Усачової (Булатова та Усачова, 2008) стверджують, що потреби, мотиви та інтереси молоді в галузі фізичної культури і спорту мають низький рівень позитивної мотивації, що пов'язано з віковими особливостями, темпераментом та соціально-економічними умовами життя.

За даними науковців О. А. Томенка та С. А. Лазоренка (2010), рівень фізичного здоров'я студентської молоді Сумської області в закладах вищої освіти знаходиться на незадовільному рівні: 63 \% юнаків мають низький рівень, $29 \%$ - нижче середнього, $8 \%$ - середній рівень соматичного здоров'я, а серед дівчат - 65 \% низький рівень, 30 \% - нижче середнього, $5 \%$ - середній рівень. Вище середнього й високий рівень соматичного здоров'я зафіксовано взагалі не було (Томенко та Лазоренко, 2010).

Також науковці (Кулик та Гудим, 2018; Постернак, 2015) свідчать про високий рівень захворюваності студентської молоді на хвороби серцевосудинної, дихальної, ендокринної та інших систем організму, які вступають до закладів вищої освіти і з кожним роком зростає кількість студентів, які відносяться до спеціальних медичних груп. А фізична підготовленість студентів основних груп перебуває, переважно, на низькому та нижчому за середній рівнях. Про прогресивне погіршення стану здоров'я дитячого населення України свідчать дані щорічних звітів Міністерства охорони 
здоров'я за 2005-2012 рр. Так, захворювання зросли на 6,9 \%, первинна захворюваність - на 10,6 \% (Поташнюк, 2014).

Питання здоров'я молоді, яка навчається в закладах вищої освіти, завжди турбує фахівців фізичного виховання, бо фізична культура важливий засіб підвищення соціальної й трудової активності людей, задоволення їх моральних, естетичних та творчих запитів, життєво важливої потреби взаємного спілкування (Головченко та Востоцька, 2018).

Так, П. М. Гунько (2008) досліджував застосування силових навантажень у процесі фізичного виховання; В. І. Романова (2010) рекомендує диференційовану програму фізичної підготовки для студенток старших курсів на основі врахування психофізичних особливостей; В.К.Бальсевич (2003) пропонує концепцію спортизації фізичного виховання; Н. І. Турчинова (2009) рекомендує проводити спеціалізовані заняття з фізичного виховання за допомогою спортивних ігор (баскетбол, волейбол, настільний теніс); І. Б. Верблюдов (2007) запропонував програму самостійного використання фізичних вправ у вигляді спецкурсу «Індивідуальна тренувально-оздоровча робота».

Виявлення ставлення студентів до викладання дисципліни «Фізичне виховання» необхідне спеціалістам для внесення корективів у навчальні програми кафедр, що надасть викладачам можливості індивідуально підходити до кожної групи, щоб забезпечити студентам, із найменшими затратами для їхнього здоров'я, пройти тернистий шлях навчання у виші.

Крім того, необхідно постійно залучати підростаюче покоління до здорового способу життя, цікавитися тими формами фізичного виховання, які популярні на даний момент серед молоді, вести серед них широку пропагандистську діяльність як змаганнями, у яких молодь безпосередньо бере участь сама, так і запрошувати їх на перегляд змагань командмайстрів, показових виступів спортсменів-розрядників.

Дослідження проводиться в межах плану науково-дослідної роботи кафедри спортивних дисциплін і фізичного виховання Навчальнонаукового інституту фізичної культури Сумського державного педагогічного університету імені А. С. Макаренка «Застосування інноваційних технологій у спорті вищих досягнень та у фізичному вихованні різних груп населення» (номер державної реєстрації 0118U100447).

Метою дослідження стало виявлення відношення студентів до процесу фізичного виховання у стінах педагогічного університету на сучасному етапі розвитку нашої держави. 
Методи дослідження. Основним методом дослідження стало анкетування. Бланки анкет, з попередньо підготовленими запитаннями, були завчасно розроблені й надані респондентам для опрацювання у вільний від занять час. Для об'єктивної оцінки ступеня надійності і достовірності отриманого матеріалу дослідження, виявлення закономірностей і змін показників, що вивчалися, при обробці цифрових даних опитування був використаний метод середніх чисел. Середню арифметичну величину $(\bar{X})$ визначали за формулою:

$$
\bar{X}=\frac{\sum_{i=1}^{n} x_{1}}{n},
$$

де $\mathrm{x}$ - значення окремого виміру;

$\mathrm{n}$ - загальне число вимірювань у групі;

і- кількість варіантів.

Для порівняння результатів опитування було використано обчислення змін показників у відсотковому відношенні, де формула виглядала таким чином:

$$
y=\frac{x_{\mathrm{B} \times 10096}}{x_{\mathrm{z}}}
$$

де $\mathrm{x}_{3}$ - загальне число опитаних;

$x_{в}$ - вибірка у групі.

Виклад основного матеріалу. Дослідження даного питання проводилося на основі анкетування 122 студентів 1-3 курсів педагогічного університету, серед яких було 48 першокурсників, 57 - другокурсників та 17 - третьокурсників. Дивлячись на стать респондентів, то серед опитаних 93 особи - жіночої статі і 29 - чоловічої.

На перше питання (рис. 1) щодо причин, які спонукають молодь до занять фізичним вихованням, рейтинг відповідей як дівчат, так і хлопців розташувався таким чином: «потреба в самовдосконаленні» (відповідно 68,8 \% та 55,2 \%); «фізіологічна потреба в руховій діяльності» (відповідно 66,7 \% та 44,8 \%); «профілактика захворювань» (відповідно 31,2% та 41,4 \%); «треба бути фізично загартованим, щоб протистояти сучасним негараздам у країні та світі» (відповідно 24,7 \% та 37,9 \%); «треба ходити заради заліку» (відповідно 18,3 \% та 10,3\%); «ліквідація наслідків захворювання організму» (відповідно 17,2 \% та 6,9%); «знадобиться колись у професійній діяльності» (відповідно 12,9 \% та 10,3%) (рис. 1). 


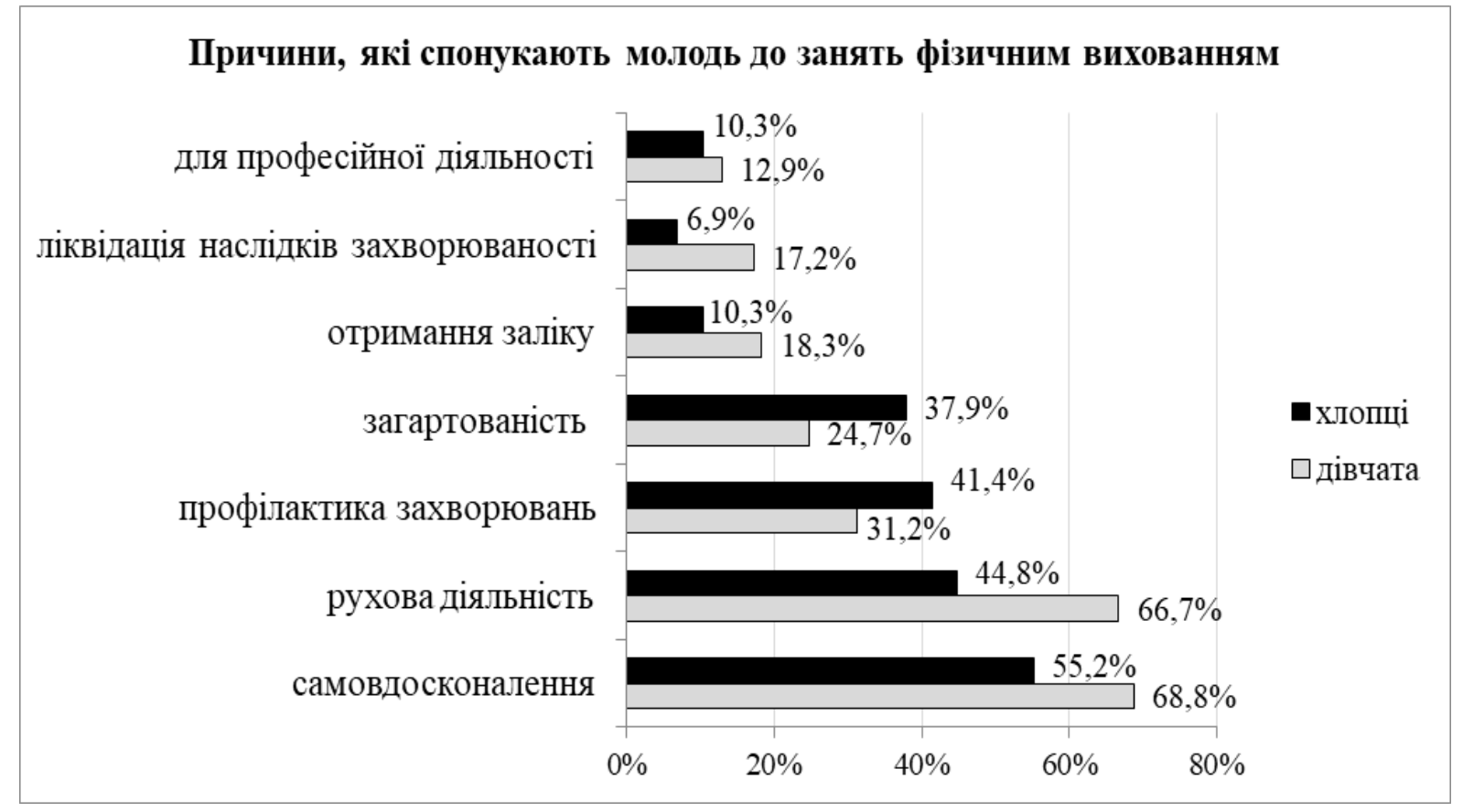

Рис. 1. Причини, які спонукають молодь до занять фізичним вихованням

За результатами наведених відповідей можна стверджувати про належне розуміння переважною більшістю студентів значення занять фізичним вихованням для самовдосконалення та підтримки рівня власного здоров'я. Як і для всього молодого покоління, переважна більшість респондентів не розуміє стратегічного значення занять фізичним вихованням у закладі вищої освіти для майбутньої успішної професійної діяльності, і що саме належна фізична підготовленість дозволить їм успішно виконувати майбутні посадові обов'язки.

Наступне питання стосувалося форм фізичної культури, які найбільш сприятливі для респондентів (рис. 2). Найбільшу кількість відповідей серед учасників анкетування набрав фактор «безпосереднє заняття фізичними вправами для фізичного вдосконалення», де серед дівчат ця кількість становила 69,9\%, а серед хлопців - $62 \%$.

Друге місце в ранжуванні було надано «можливості переключитися на рухову активність, щоб зняти розумову втому», де відсоткове співвідношення серед студенток і студентів становило відповідно 50,5 \% та 34,3 \%. Третє місце та наступні були розподілені таким чином: «перегляд спортивних змагань на трибунах» (17,2 \% і 10,3 \%); «перегляд періодичних спортивних видань» (3,2 \% і 10,3 \%); «інший напрямок» (3,2 \% і 10,3 \%); «не цікавлять ніякі форми» (3,2 \% і 6,8 \%); «перегляд спортивних програм по телебаченню, комп'ютеру» (2,1% і 3,4%). 


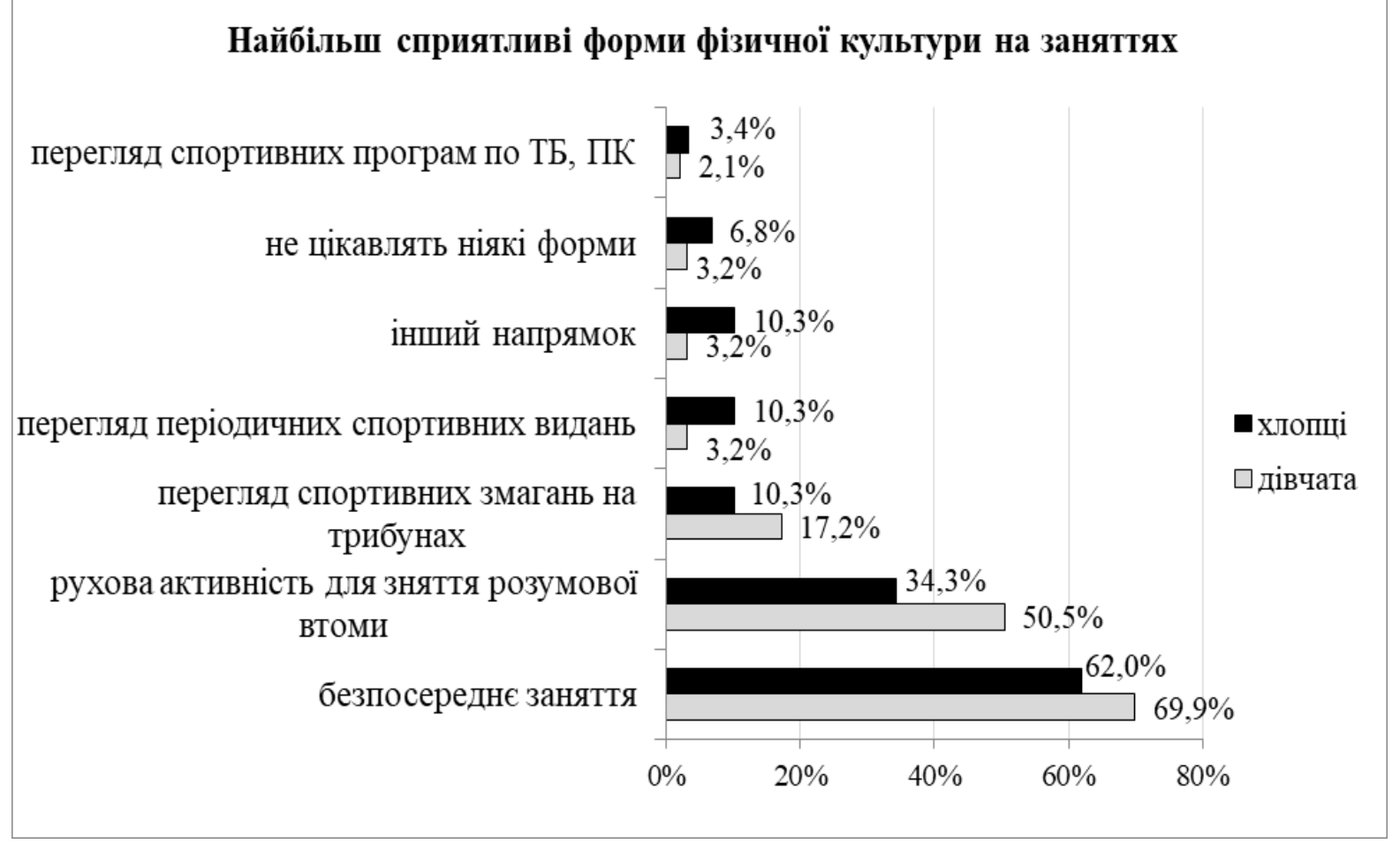

Рис. 2. Найбільш сприятливі форми фізично культури на заняттях

Дослідження вищевказаного питання вказує, що крім відвідування занять фізичного виховання молодь не цікавиться спортивним життям як свого 3ВО, міста, так і Всеукраїнських, Європейських та світових першостей з видів спорту. Але ж саме цей напрям виявлення найсильнішого має велике значення у виховному процесі підростаючого покоління.

На запитання «чому вам не подобаються заняття з фізичного виховання» (рис. 3), учасники анкетування відповіли таким чином. 41,9\% дівчат та 44,8 \% хлопців основною причиною зазначеної проблеми вказали «нестача часу у зв'язку з великим навчальним навантаженням». Другу позицію у дівчат (23,6\%) та третю у хлопців (24,1 \%) отримала відповідь «сам додатково займаюся руховою активністю». А на друге місце хлопці поставили відповідь «слабка матеріально-технічна база навчального закладу» $(34,5 \%)$, де цей фактор у дівчат підтримала переважна меншість, а саме 12,9 \%.

Далі по рейтингу розташувалися такі відповіді, а саме: «інші причини», де відсоток відповідей дівчат і хлопців становив відповідно 16,1 \% та 13,7 \%; «навпаки, мені подобаються» - відповідно 12,9 \% і 3,4 \%; «пусте витрачання часу, де заняття нічого не дають» - відповідно 3,2 \% та $3,4 \%$. Наступні два фактори негативного ставлення до занять фізичним вихованням «пусте витрачання часу, краще б провести час за смартфоном» та «особиста неприязнь до викладача, який проводить заняття з фізичного виховання» взагалі не отримала підтримки у опитаних. 


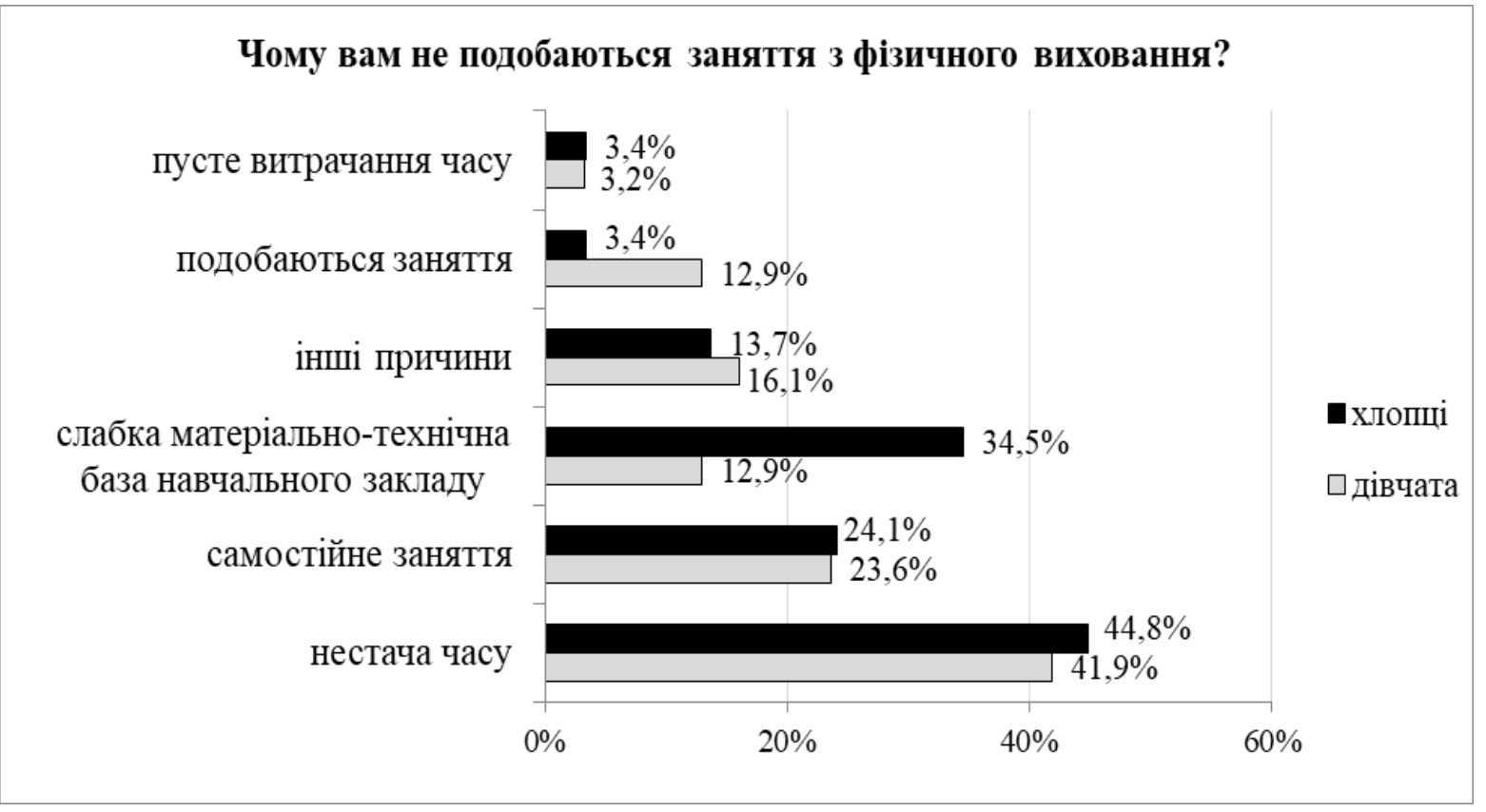

Рис. 3 Відповіді на питання чому не подобаються занятяя з фізичного виховання

Аналіз цього питання вказує на відсутність у студентів системи планування свого робочого часу, бо половина з них бідкається про велику завантаженість під час навчального процесу, де немає місця годині активного відпочинку, як того потребує людський організм. Позивного моменту заслуговує те, що четверта частина респондентів вміє самостійно запланувати активний відпочинок. Щодо слабкої матеріально-технічної бази, на яку вказує третя частина юнаків та невелика кількість дівчат, то дуже складно забезпечити кожного індивідуально інвентарем саме того виду спорту, якого він бажає, серед великої кількості учасників спортивно-оздоровчого процесу.

Для виявлення думки респондентів щодо покращення процесу фізичного виховання було запропоновано низку пропозицій, де рейтинг їхнього рішення розташувався наступним чином. На перше місце дівчата поставили відповідь «проводити заняття улюбленим видом спорту» $(67,7$ \%), у той час як у хлопців це зайняло друге місце (48,2 \%) (рис. 4). Бо на перше юнаки запропонували «проводити заняття на спеціалізованих спортивних майданчиках» (58,6 \%), у той час як ця пропозиція посіла в дівчат третю сходинку (33,3 \%). На друге місце дівчата поставили «застосовувати більше спортивного обладнання» (46,2\%), де цей фактор у хлопців посів третє місце (44,8\%). Далі по рейтингу виступили «підвищити фізичне навантаження» (у дівчат відсоток склав 15,1 одиниць, у хлопців - 20,7); «зменшити фізичне навантаження» - відповідно 8,6 \% та 6,8 \%; «інші пропозиції» $(5,4 \%)$ висунули тільки дівчата-першокурсниці. А напрям «замінити викладача 3 фізичного виховання» не підтримав жоден з респондентів (рис. 4). 


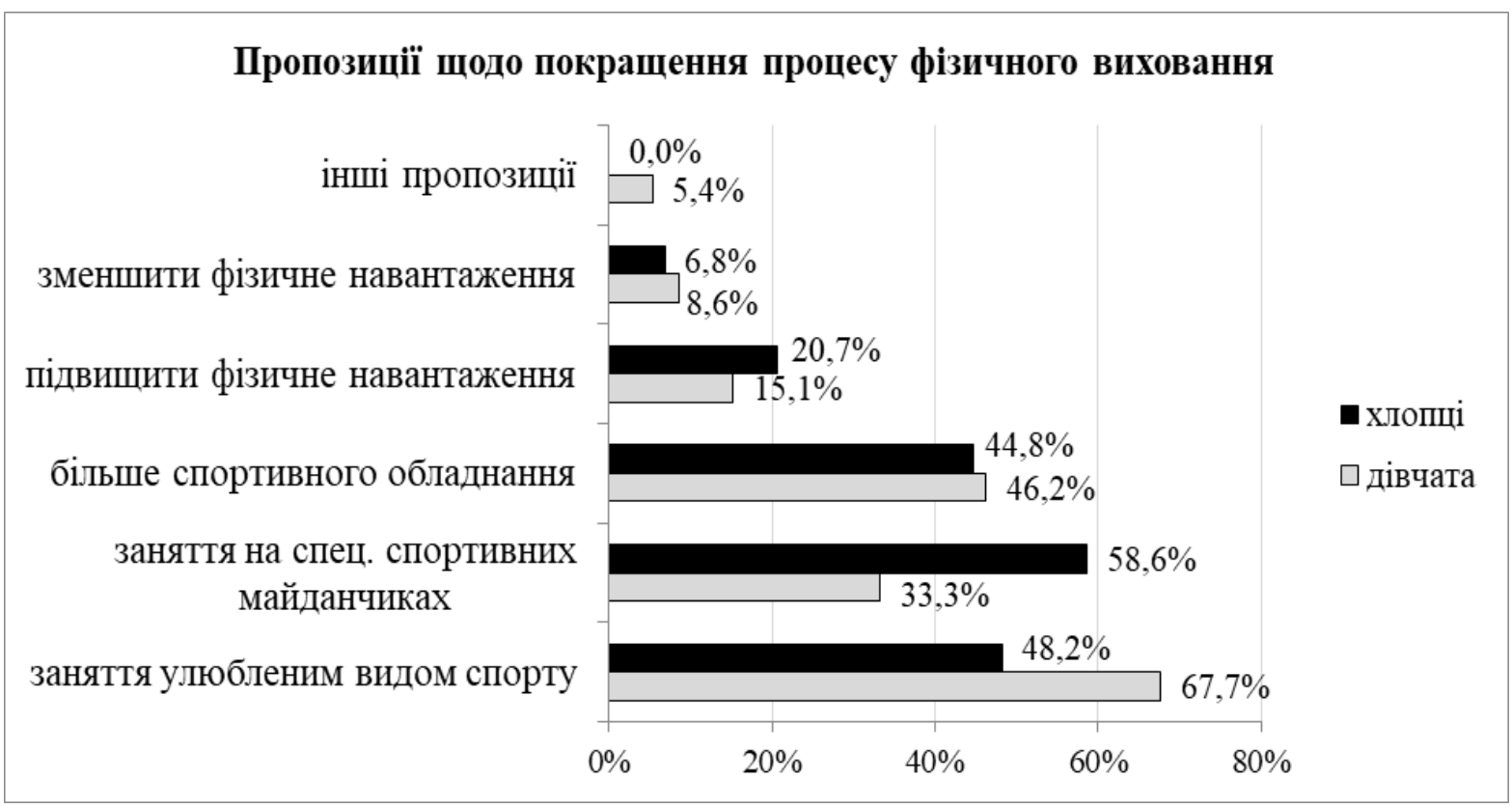

Рис. 4. Пропозиції щодо покращення процесу фізичного виховання

Як свідчать отримані відповіді на вищевказане питання, молодь бажає задовольняти свою потребу в руховій активності тим видом спорту, який їм до вподоби, та ще й на спеціалізованих майданчиках, обладнаних сучасним інвентарем. Позитивним є той факт, що молодь бажає підвищити фізичне навантаження.

Щоб виявити бажання студентів використовувати під час занять певні види спорту, до анкети було введено 15 пропозицій, аналіз яких виявив наступне. Якщо найбільшу кількість голосів у дівчат (51,6\%) набрала "ритмічна гімнастика», то хлопці першочергово займалися 6 як «ритмічною гімнастикою», так і «настільним тенісом» та «йогою» (усі три види спорту набрали по 58,6\%). На друге місце дівчата поставили «волейбол» (46,2\%), у той час як хлопці - «легку атлетику» (біг на короткі та середні дистанції), «стройові вправи» та «шахи» (48,2\%). Третю сходинку в дівчат посіли "рухливі ігри та естафети» (43\%), а у хлопців «баскетбол» і «плавання» (44,8 \%).

Далі по рейтингу дівчата проголосували за «йогу» (41,9\%), «силові вправи для окремих м'язових груп» (34,4\%), «бадмінтон» (30,1\%), «туристичні походи» (27,9\%), «плавання» (26,8\%), «футбол» $(23,6 \%)$, «баскетбол» і «настільний теніс» (19,3\%), «легка атлетика» і «шахи» $(17,2 \%)$, «флорбол» (11,8 \%), «стройові вправи» (8,6\%), «інше» (3,2 \%).

На четверте місце хлопці поставили «футбол», «туристичні походи» та «інше», за що проголосувало 20,7\% респондентів. Останніми по рейтингу видами спорту стали «волейбол» та «бадмінтон» з кількістю 
набраних голосів по 6,8 \%. Не набрали жодної відповіді «силові вправи для окремих м'язових груп», «рухливі ігри та естафети», «шахи» та «флорбол». Аналіз цього питання вказує на те, що респонденти хочуть оздоровлюватися різноманітними формами рухової активності і для цього треба створювати належні умови матеріально-технічного забезпечення.

Передостаннім питанням анонімного анкетування було виявлення думки респондентів щодо зміни їхнього позитивного відношення до занять фізичним вихованням після закінчення вищого навчального закладу. Як дівчата $(65,6 \%)$, так і хлопці $(72,4$ \%) у своїй більшості висловили бажання і «надалі займатися підвищеною руховою активністю, але самостійно». Друге місце зайняв фактор теж позитивного відношення «і надалі займатися підвищеною руховою активністю з відвідуванням платної фізкультурно-оздоровчої секції», де за дану пропозицію проголосувало $25,8 \%$ дівчат та 27,5 \% хлопців. Щодо негативного ставлення до занять фізичним вихованням з формулюванням «бо моє фізичне здоров'я не потребує додаткових занять підвищеною руховою активністю», то респондентів виявилася значна меншість, а саме $11,8 \%$ дівчат та $13,7 \%$ хлопців. І тільки двоє студенток, або ж 2,4\%, виділили фактор «так, бо краще витрачати гроші на ліки (які швидко покращують стан здоров'я), а не витрачати час та кошти на спортивні зали».

Аналіз цього питання вказує, що переважна більшість опитаних i після закінчення активного втручання держави в їхню фізичну підготовку буде приділяти увагу своєму активному дозвіллю, але без втручання фахівців галузі фізичної культури і спорту. На нашу думку, це визвано нинішнім скрутним матеріальним становищем населення України, коли сім'я не може виділити кошти для занять під наглядом кваліфікованого фахівця з фізичної культури і спорту.

Для виявлення відношення студентів 3 курсу «щодо проведення занять фізичним вихованням тільки один раз протягом тижня» було запропоновано три позиції, серед яких найбільшу кількість голосів як у дівчат, так і у хлопців набрала пропозиція «цілком влаштовує», відповідно 54,5\% та $100 \%$. Друге місце дівчата віддали фактору «треба повернути дворазові заняття фізичним вихованням» $(36,4$ \%) та одна студентка $(4,1 \%)$ вказала на «повністю ліквідувати заняття фізичним вихованням, бо вони заважають навчатися».

Аналіз цього питання вказує, що половина дівчат-третьокурсниць розуміють наслідки скорочення активної рухової активності при переході у старшу вікову групу від дівчини до жінки, а з половиною дівчат та всіма 
юнаками треба вести роз'яснювальну роботу щодо корисності регулярних занять фізичним вихованням на організм дорослої людини.

\section{Висновки та перспективи подальших наукових розвідок.}

1. Більшість студентів-педагогів університету правильно розуміють значущість процесу фізичного виховання для особистого здоров'я, формування та набуття життєво важливих рухових умінь, навичок та спеціальних знань.

2. Для покращення процесу фізичного виховання в педагогічному закладі вищої освіти необхідно:

- проводити заняття з середнім та значним фізичним навантаженням для посилення адаптаційних можливостей молодого організму;

- у фізичних вправах більше використовувати різноманітний спортивний інвентар та обладнання;

- створювати належні умови різноманітної рухової активності;

- постійно оновлювати матеріально-технічну базу для занять фізичною культурою і спортом, яка відповідає сучасним технологічним стандартам.

3. Постійно проводити роз'яснювальну роботу з приводу професійноприкладного значення фізичних вправ, які використовуються на заняттях фізичним вихованням у закладах вищої освіти, для розвитку тих фізичних якостей, необхідних у майбутній професійній діяльності.

Майбутні дослідження будуть спрямовані на розробку методики проведення занять із фізичного виховання, яка матиме професійно-прикладне значення в роботі фахівців освітніх закладів згідно обраної спеціальності.

\section{ЛІТЕРАТУРА}

Указ Президента України «Про Начіональну стратегію з оздоровчої рухової активності в Україні на період до 2025 року «Рухова активність - здоровий спосіб життя - здорова нація» (2016). Режим доступу: https://zakon.rada.gov.ua/laws/show/42/2016. The President of Ukraine Decree № 42 of 2016 "On the National Strategy for the Motor Activity Improvement in Ukraine until 2025 "Motor Activity - Healthy Lifestyle - Healthy Nation" (2016). Retrieved from: https://zakon.rada.gov.ua/laws/show/42/2016.

Баліцька, Є. П. (2013). Мотивація студентів до занять фітнесом в технічному вищому навчальному закладі. Педагогіка, психологія та медико-біологічні проблеми фрізичного виховання і спорту, 6, 3-6 (Balitska, Ye. P. (2013). Students' motivation for fitness classes at the technical higher education institution. Pedagogics, psychology and medical and biological problems of physical education and sports, 6, 3-6).

Булатова, М. М., Усачов, Ю. О. (2008). Сучасні фізкультурно-оздоровчі технології у фізичному вихованні. Теорія і методика фізичного виховання, 2, 320-354 (Bulatova, M. M., Usachev, Yu. O. (2008). Modern Physical and Wellness Technologies in Physical Education. Theory and Methods of Physical Education, 2, 320-354).

Головченко, О., Востоцька, І. (2018). Теоретичні та практичні умови формування всебічно розвиненої особистості засобами фізичної культури і спорту. Педагогічні науки: теорія, історія, інноваційні технології, 3 (77), 57-67 
(Holovchenko, O., Vostotska, I. (2018). Theoretical and practical conditions for the formation of a fully developed personality by means of physical culture and sports. Pedagogical sciences: theory, history, innovative technologies, 3 (77), 57-67).

Кузнєцова, О., Зубрицький, Б., Сініцина, О. (2015). Визначення рівня фізичної підготовленості студентів першого курсу університету. Фізичне виховання, спорт і культура здоров'я у сучасному суспільстві, 3 (31), 147-152 (Kuznetsova, O., Zubrytsky, B., Sinitsyna, O. (2015). Determination of sophomores' physical preparedness level at the university. Physical education, sport and health culture in modern society, 3 (31), 147-152).

Кулик, Н. А., Гудим, С. В. (2018). Рівень здоров'я студентів-першокурсників при вступі до закладів вищої освіти. Актуальні проблеми фізичного виховання різних верств населення, 144-151. Режим доступу: http: //hdafk.kharkov.ua/ua/naukovarobota/naukovo-teoretichni-vidannya/aktualni-problemi-fizichnogo-vikhovannyariznikh-verstv-naselennya. (Kulyk, N. A., Hudym, S. V. (2018). Sophomores' health level when entering higher educational establishments. Current problems of physical education of different sections of the population, 144-151). Retrieved from: http: //hdafk.kharkov.ua/ua/naukova-robota/naukovo-teoretichni-vidannya/aktualniproblemi-fizichnogo-vikhovannya-riznikh-verstv-naselennya).

Постернак, І. В. (2015). Особливості фізичного виховання студентів спецмедгруп при захворюваннях органів травлення та печінки. Фізичне виховання, спорт $i$ здоров'я людини. Вісник Кам'янець-Подільського національного університету імені Івана Огієнко, 8, 281-288 (Posternak, І. V. (2015). Physical education peculiarities of students of special groups with digestive and liver organs diseases. Physical education, sport and health of a person. Bulletin of Ivan Ogienko KamianetsPodilsky National University, 8, 281-288).

Поташнюк, І. (2014). Стан психологічного здоров'я учнів загальноосвітніх закладів і стратегія його зміцнення. Фізична культура, спорт та здоров'я нації, 18 (1), 229-235 (Potashniuk, I. (2014). The students' psychological health state of general education institutions and its strengthening strategy. Physical Culture, Sport and Nation Health, 18 (1), 229-235).

Сотник, О. (2013). До проблеми викладання фізичного виховання у вищих навчальних закладах. Фізична культура, фізичне виховання різних груп населення. Фізичне виховання, спорт і культура здоров'я у сучасному суспільстві, 1 (21), 251-256 (Sotnyk, O. (2013). The problem of teaching physical education at higher educational establishments. Physical culture, physical education of different population groups. Physical education, sports and health culture in modern society, 1 (21), 251-256).

Томенко, О. А., Лазоренко, С. А. (2010). Рівень соматичного здоров'я і рухової активності студентів вищих навчальних закладів. Слобожанський науковоспортивний вісник, 2, 17-20 (Tomenko, О. A., Lazorenko, S. A. (2010). Students' physical health level and motor activity at higher educational establishments. Slobozhanskyi scientific and sports newsletter, 2, 17-20).

Masliak, I., Bala, T., Krivoruchko, N., Shesterova, L., Kuzmenko, I., Kulyk, N., Stasiuk, R., Zhuk, V. (2018). Functional state of cardiovascular system of 10-16-year old teenagers under the influence of cheerleading classes. Journal of Physical Education and Sport (JPES), 18 (1), Art 63, 452-458. 


\section{PEЗЮME}

Мищенко Александр, Кулик Нина, Прийменко Лариса, Мищенко Александр. Отношения студентов-педагогов к процессу физического воспитания в высших учебних заведениях.

Отношения студентов к прочессу физического воспитания в стенах педагогического университету на современном этапе развития нашего государства. Анализ анонимного анкетирования указывает, что для улучшения прочесса физического воспитания в высшем педагогическом учебном заведении необходимо применять ряд факторов, представленных к рассмотрению авторами опроса, среди которых респонденты определили, по их мнению, значимые, а именно повышение физической нагрузки, использование разнообразного спортивного инвентаря и оборудования, создание условий для разнообразной двигательной активности, постоянного обновления материально-технической базы.

Ключевые слова: здоровья, студент, физическое воспитание, материальнотехническое обеспечение, фризическая нагрузка.

\section{SUMMARY}

Mischenko Oleksandr, Kulyk Nina, Prymenko Larysa, Mischenko Oleksandr. Students-teachers' attitude to the physical education process at the higher educational establishment.

The study results of the students' attitude to the physical education process at the pedagogical university at the present stage of our state development are presented in the article. As to the issue of youth health, that is studied at higher education institutions, is always a matter for physical education of professionals, because physical culture is an important means for increasing people's social and labor activity, satisfying their moral, aesthetic and creative demands, and the vital needs of mutual communication. Identifying the students' attitude to the discipline "Physical education" is necessary for specialists to make adjustments to the departments' curriculum, which will enable teachers to individually approach each group, in order to provide students with the least cost for their health, to undergo a thorny path of study at the university. In addition, it is necessary to constantly involve the younger generation in a healthy lifestyle, to be interested in the forms of physical education that are popular nowadays among young people, to conduct among them a wide range of propaganda activities like competitions in which young people directly participate, and to invite them for viewing teammasters' competitions, qualified athletes' demonstrative performances.

The anonymous questionnaire analysis has shown that most university students correctly understand the significance of the physical education process for personal health, formation and acquisition of vital motor skills and special knowledge. Accordingly in order to improve the physical education process at the higher education institution it is necessary: to increase the young organism's adaptive capacity to conduct classes with moderate and significant physical activity; to use various sports equipment; to create proper conditions for different motor activity, for physical education and sports, to update constantly the material and technical base for development of physical qualities necessary for future professional activity, to carry out constantly an explanatory work about the professional-applied value of physical exercises used during physical education classes at higher educational establishments.

Key words: health, student, physical education, material and technical support, physical activity. 